\title{
ROLE OF THE HISTAMINE H3-RECEPTOR IN HEPATORENAL INFLAMMATORY INJURIES INDUCED BY SCORPION VENOM
}

\author{
Megdad-Lamraoui A., Adi-Bessalem S., Laraba-Djebari F. \\ amal.lamraoui@outlook.fr
}

USTHB, Faculty of Biological Sciences, Laboratory of Cellular and Molecular Biology, BP 32, El-Alia Bab Ezzouar, 16111 Algiers, Algeria

\section{TYPE OF ARTICLE: CONFERENCE ABSTRACT}

\begin{abstract}
Background: The activation of the inflammatory response and the release of pro-inflammatory mediators such as cytokines and vasoactive substances play an important role in the pathophysiology of scorpion envenomation. The mechanism of the hepatorenal inflammation response induced by scorpion venom has not yet been completely elucidated.

Methods: The aim of this study was to investigate the role of histamine H3-receptors in hepatorenal tissue inflammation and oxidative stress following experimental scorpion envenomation. Hepatorenal inflammation was assessed by colorimetric methods evaluating the index of increased vascular permeability, the myeloperoxidase and the eosinophil peroxidase activities markers of neutrophil and eosinophil cells in these tissues. Lipid peroxidation expressed as malondialdehyde level and glutathione were measured to assess the oxidative stress. This study is supported by histological analysis where the sections were stained with hematoxylin and eosin. This study was performed in the Laboratory of Cellular and Molecular Biology of the Biological Sciences Faculty at the Houari Boumediene University of Sciences and Technology (USTHB) in 2013.

Results: Envenomed mice displayed an installation of an inflammatory response marked by cell infiltration preceded by an increase of the hepatic $(6.25 \pm 0.57 / \mu \mathrm{g}$ of tissue, $\mathrm{p}<0.05)$ and the renal $(32.46 \pm 1.12 / \mu \mathrm{g}$ tissue, $\mathrm{P}<0.001$ ) vascular permeability compared to controls (liver: $3.72 \pm 1.70 / \mu \mathrm{g}$ of tissue; kidney: $9.78 \pm 0.99 / \mu \mathrm{g}$ de tissue). Imbalanced redox status with decreased catalase and glutathione activities, and increased malondialdehyde level with alterations of hepatorenal tissues were observed. Pre-treatment of animals with histamine H3-receptor antagonist before venom injection, significantly decreased the vascular permeability $(\mathrm{p}<0.05)$, edema formation and tissue recruitment of inflammatory cells. Lipid peroxidation products, glutathione and catalase activities were significantly reduced $(\mathrm{p}<0.05)$. These disorders were accompanied by a reduction of anatomopathological alterations induced by the venom.

Conclusion: These results suggest that the histamine, by acting on the $\mathrm{H} 3$ receptor is involved in the triggering of the inflammatory response and also in the alteration of the oxidant/antioxidant balance in the hepatorenal tissues caused by the venom.
\end{abstract}

KEYWORDS: Hepatorenal inflammatory response, Histamine H3 receptor, Oxidative stress, Scorpion venom

\footnotetext{
Abstracts of Third International Conference on Health Sciences and Medical Technologies, October 2018, Tlemcen, Algeria (ICHSMT-18)

(C) 2019 The Authors. This is an open access article under the terms of the Creative Commons Attribution-NonCommercialNoDerivs License, which permits use and distribution in any medium, provided the original work is properly cited, the use is non-commercial and no modifications or adaptations are made.
} 